\title{
Correction: Fifteen-minute consultation: Preseptal and orbital cellulitis
}

Adamson J, Waterfield T. Fifteen-minute consultation: Preseptal and orbital cellulitis. Archives of Disease in Childhood - Education and Practice 2019;104:79-83. doi: 10.1136/archdischild-2017-314297

Figures 2 and 3 in this paper were published without the proper credit of their source. The caption for Figure 2 should have included "Author: Afrodriguezg. (https://commons.wikimedia.org/wiki/File:Celulitis_Periorbitaria_(Preseptal). JPG), Celulitis Periorbitaria (Preseptal). https://creativecommons.org/licenses/bysa/3.0/legalcode

Figure 3 should have included the credit: Jonathan Trobe, University of Michigan Kellogg Eye Center (https://commons.wikimedia.org/wiki/File: Orbital_cellulitis.jpg). Orbital cellulitis. https://creativecommons.org/licenses/ by $/ 3.0 /$ legalcode

(C) Author(s) (or their employer(s)) 2019. No commercial re-use. See rights and permissions. Published by BMJ.

Arch Dis Child Educ Pract Ed 2019;104:280. doi:10.1136/ archdischild-2017-314297corr1

Check for updates 